\section{Tântalo da vontade, plebeu aventureiro: a Cultura filosófica de Simmel}

SIMMEL, Georg. Cultura filosófica (tradução de Lênin Bicudo Bárbara; apresentação de Leopoldo Waizbort). São Paulo: Editora 34, 2020.

Vinícius Madureira Maia (https://orcid.org/0000-0001-5301-0155), Programa de Pós-Graduação em Sociologia da Universidade de São Paulo (PPGS-USP), São Paulo, Brasil'.

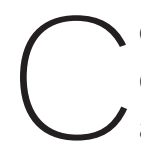

onhecem-se várias comparações a que a figura intelectualmente plástica de Georg Simmel pareceu estar sujeita. Atribui-se amiúde a Ortega y Gasset aquela conforme a qual Simmel se assemelhava a uma espécie de "esquilo filosófico" que, saltando de galho em galho, perpassa por todas as nozes um tanto despreocupado em mordiscar qualquer uma delas, entretecendo-se, acima de tudo, com a destreza de seus próprios pulos. Ora, em que pese ao possível e sutil desdém inconsciente ou sub-reptício na poética de tal analogia, o livro Cultura filosófica, recém-traduzido e publicado pela Editora 34, oferece agora aos leitores de língua portuguesa 14 amostras de suas esplêndidas acrobacias espirituais.

Primeira de um par de antologias organizadas pelo próprio autor, a tradução integral da Philosophische Kultur assoma, entre nós, feito um autêntico "acontecimento", no sentido filosófico que o francês empresta ultimamente ao termo. A propósito, 20 anos antes, a mesma casa trazia a público um marco na fortuna crítica de Simmel, hoje em sua terceira edição: As aventuras de Simmel, de Leopoldo Waizbort (2000), autor de vários outros trabalhos sobre o sociólogo berlinense, entre eles a apresentação a essa edição da Cultura filosófica. Não se pode esquecer, de outra parte, que o livro nos chega deploravelmente com pouco mais de um século de atraso: a primeira edição viera a lume em 1911 e foi revista em 1918. As razões para tal retardo são tão numerosas quanto inconcludentes, se tomadas em isolado. Mesmo na Alemanha, a Philosophische Kultur demorou a lograr reedição; a terceira e então penúltima surgiu em 1923, e foram necessários exatos 60 anos para ressurgir uma quarta, fato cuja peculiaridade talvez revele o quão próximo e, a um só tempo, demasiado distante de nós Simmel se encontra enquanto crítico da cultura,
I. Vinícius Madureira Maia é doutorando em sociologia junto ao Programa de Pós-Graduação em Sociologia da Universidade de São Paulo (PPGS-USP). $<$ vi.madureira@ gmail.com> 
como nos lembra Habermas (2015: 253-274) em elucidativo posfácio a essa quarta aparição, intitulado "Simmel als Zeitdiagnostiker", de 1983, mais tarde incluído em sua coletânea Textos e contextos.

Seria vão imaginar que se poderia aqui destacar tudo o que há de conspícuo e proveitoso nesse livro, em vista do espaço reduzido que na maior parte dos casos é destinado às resenhas - paciência, Cultura filosófica há de atrair glosas bem mais longas e propícias. Dada a variedade de assuntos nela tratados, os quais, uma vez reunidos, segundo advertência do próprio autor, nada dispõem em comum no tocante à matéria, à exceção do "impulso metafísico" que, por mais heterogêneo, arroja-se sobre cada um dos temas, encontro-me talvez em condições de comentar satisfatoriamente apenas a abordagem incomum (ou original, da cultura sub specie ludi et philosophæ) a que Simmel ali se propôs, bem como algumas razões possíveis de seu insucesso.

Sem recair no velho axioma da crítica literária sainte-beuviana, a saber, o da relação visceral entre autor e obra, para se compreender o descaso com a Cultura filosófica talvez seja o caso de não esquecer a natureza combinada de seu escritor, metade citadino, metade ser campônio. Outro grande privilégio que coube a alguém nascido emblematicamente no cruzamento das ruas comerciais de maior afluência no recanto por excelência da modernidade - a capital prussiana, a cidade imperial de Berlim no segundo meado do século XIX -, e que só a contragosto, na última porção da vida, pôde respirar o ar mais puro da província: o seu espírito circunspecto, o olhar agudo, circunstanciado, atraído pelo miúdo e ordinário da existência (desde o "conforto proporcionado pelas nossas roupas velhas à grandeza esmagadora dos Alpes"; do "flerte da coquete" ao "formato da asa dos vasos japoneses"; da personalidade de Deus à "pátina que, com o tempo, recobre certos materiais, conferindo aparência peculiar a estátuas e edifícios"); puerilmente debruçado sobre naturezas-mortas, movido como que por uma inclinação algo bucólica, paciente, campestre, remansosa, incrivelmente excepcional em meio a uma sociedade cada vez mais urbana, acelerada, fugazmente dispersa, há muito desacostumada ao esforço refletido de toda contemplação, distraída por miríades de estímulos nervosos, cuja condição frenética, típica da vida mental metropolitana, ele próprio também cuidou de prever e matizar.

Simmel, em todo caso, não se limitou a representar os objetos em si, nada de seu aspecto primordialmente visível, habitual; pintava-os com grandes traços que, à guisa do Cézanne de Merleau-Ponty, dão antes a "fisionomia moral dos gestos", daqueles gestos singulares, "crescendo cada vez mais no inconsciente", que geram de si mesmos "o corpo que lhes pertence" - é o movimento que constrói seu 
corpo, nas palavras do próprio Simmel, é a vida que constrói sua forma; pintava mais: o próprio ato de olhar, a vista lançada aos objetos, não estes como se deixam avistar. Logo, para se fazer justiça à comparação de Lukács (2018: 328), de que a situação histórica do filósofo berlinense poderia ser formulada nos seguintes termos: "ele foi um Monet da filosofia, a quem não se seguiu, até hoje, nenhum Cézanne", é necessário corrigi-la pelo menos em parte: para além do prejuízo que a mera qualificação de "impressionista" parece provocar, com o emprego de múltiplas perspectivas, pinceladas analíticas, uma paleta de cores vívidas, Simmel foi, a bem da verdade, um Cézanne da filosofia, após o qual não sobreveio nenhum Picasso - e para cuja atitude e ressurgimento é preciso, sobretudo, ser genuinamente francês no gosto, à maneira de um Chardin, Proust, Rodin, Matisse. A meu sentir, não é talvez exagero supor que a cuidadosa tradução de Cultura filosófica ${ }^{1}$ parece conceder ao leitor o vislumbre daquele estilo pictórico saudável e imaginativo, nada sobrecarregado - mas sinuoso -, tal como idealizado por um certo psicanalista suíço (Jung, 1999: 337), que dizia não o enxergar nos traços de um Nietzsche, por exemplo.

A propósito, a produção de Simmel, que resguarda afinidades temáticas e estruturais, não exatamente estilísticas, com a de Nietzsche, é fundamentalmente esparsa, multipontilhada e pouco sistemática, ou mesmo antissistemática. Inadvertida ou propositalmente, a Cultura filosófica assume uma feição compendiosa, constitui - ou serve como - uma espécie de síntese ou de introdução ao pensamento de seu autor. Os ensaios comparecem aí em pares agrupados sob um mesmo tema psicologia filosófica, filosofia dos sexos, estética, personalidades estéticas, filosofia da religião e, afinal, filosofia da cultura -, no total de sete, introdução inclusa, pois considerada um ensaio autônomo. Se permitido aqui o destaque de uma única seção, os ensaios intitulados "A personalidade de Deus" e "O problema da situação religiosa", mesmo passados 100 anos, assomam, entre os demais, porventura dignos de ainda maior atenção. Neste último, a previsão de Simmel (p. 252-253) acerca de uma religiosidade futura, sem meios e mediações, sem "constructos transcendentais" e o relacionamento com estes, como que prepara, de certa forma, as contribuições de um Thomas Luckmann à sociologia da religião, sobretudo a concepção de que, na modernidade, diminuem paulatinamente tanto o significado da ordem social transcendental, como as respectivas transcendências primordiais, embora o próprio Luckmann repute extremamente improvável o completo desaparecimento do sagrado (cf., a propósito, Mata, 2014: 191-194) - à exceção da hipótese de uma transformação radical da constituição humana, ou seja, que esta se torne imperecível um dia, pois o homem ainda é um ser que morre e, pior, vê morrer o seu entorno. Para Hegel, físicos puros, genuínos, são de fato apenas os animais, que não filosofam; já o homem, enquanto ser pensante, seria um metafísico nato. Logo, do
1. Diligentemente acompanhada, aqui e ali, de notas relativas a impasses filológicos e problemas

"técnicos". Nada obstante, a meticulosidade de tal esforço destoa da ausência de glossário e índice remissivo em edições de obras do tipo, repleta de sintaxes e alusões a que Horst J. Helle (Simmel, 2013) julgandoas embaraçosas ao leitor

contemporâneo, não titubeou ao dar-lhes nova formulação em tradução para o inglês. O tradutor, de todo modo, assumiu ainda a árdua tarefa de cascaviar citações expressas e referências implícitas de Simmel, com cujo ânimo Lênin enriquece sobremaneira a experiência (e a cultura) dos leitores. 
2. Autor do expressivo Simmel and "the social" (2010), livro no qual consigna que a relevância atual de Simmel residiria precisamente em sua compreensão do "social" - o objeto por excelência da sociologia - em termos de processo e de relações.

3. Os encantamentos das lições de Simmel talvez só viessem a conhecer rivalidade algo equivalente, tempos depois, na ambiência de outra metrópole e vida do espírito, isto é, na Paris dos disputadíssimos seminários de Jacques Lacan outro excomungado artífice do verbo -, encenados nos átrios da Normale Sup' ao longo das décadas de 1950 e 1960. ponto de vista puramente teológico, é uma nulidade a religião (cristã, islâmica etc.) não transcendental: não serve para o consolo, tampouco à salvação. Uma deidade além ou "entre físico e metafísico", como lembra Christoph Türcke (1993: 30), "não foi descoberta em nenhum lugar, nem mesmo na Bíblia, onde Deus Pai ou é imaginado de modo ingênuo, a saber, antropomorficamente, ou é pensado rigorosamente [...] como o metaphysicum imaterial enquanto tal": tertium non datur (p. 232). O que, de uma maneira decerto curiosa, justificaria o estranhamento da grã-duquesa de Baden a respeito de Simmel: ele Ihe parecia pouco afeito às Escrituras (Bibelglaubig). Também nesse aspecto, a Cultura filosófica anteciparia a aparência de um "ateísmo gnóstico" que Jaspers vai divisar com alguma dificuldade no Heidegger (Heidegger \& Jaspers, 1990) dos Caminhos da Floresta.

De resto, assim como a maior parte dos livros de Nietzsche, a Cultura filosófica de Simmel se depara, por sua vez, como uma miscelânea menor de reflexões e sentenças, não tão espraiadas, curtas ou incisivas quanto os aforismos pelos quais o primeiro passaria à posteridade. A obra de Nietzsche, que não conheceu reconhecimento em vida, é a segunda mais vendável em todo o mundo, atrás apenas dos manuscritos de Platão; e a lista de seus epígonos, incomensurável. Em contrapartida, o sociólogo finlandês Olli Pyyhtinen (2015: 15)² afirma, sem qualquer resignação, que "a história intelectual não conhece simmelianos". A constatação é sobremaneira desconcertante. Tanto mais ao se ter notícia de que centenas de pessoas, não apenas jovens ou estudantes, acorriam semanalmente ao auditório da então chamada Friedrich-Wilhelms-Universität, em Berlim, para lá assistir as magníficas aulas por ele ministradas. "Eram momentos emocionantes. Não se podia fugir de modo algum do sortilégio", na recordação de um nostálgico espectador; são inúmeros os depoimentos e testemunhos nesse sentido, acerca do poderio quase sobrenatural de sua atuação pedagógica sobre plateias apinhadas e aturdidas ${ }^{3}$ (cf. Waizbort, 2000: 50 e 571-588). Com Simmel, parecia entrar intempestivamente em cena, na ágora acadêmica, a encarnação milenar de um vulto transfigurado de filósofo clássico, como só houve igual na época trágica dos gregos. Essa afluência de ouvintes maravilhados não era, contudo, unânime e institucionalmente encarada com simpatia, como se pode adivinhar das desgostosas classes tradicionais. Embora o fenômeno em geral Ihe parecesse inevitável, Max Weber, por exemplo, dizendo-se imbuído de experiência pessoal já bastante ampla e fundamental a reflexões ditas isentas de qualquer fantasia, desconfiava fortemente dos cursos procurados por massas enormes, as quais sairiam à cata de professores quase sempre instigadas por razões em grande parte alheias à ciência em si, seja o temperamento do docente, a inflexão de sua voz, o assunto da vez etc. No âmbito da educação científica ministrada no ensino superior alemão, com respeito e máxima fidelidade à tradição, esse aspecto popular do conhecimento não poderia ser senão inconveniente, uma 
vez que o trabalho de instrução constituía, a seu ver, não um mister democrático, não essa ordinária subordinação à "obsessão da sala cheia", mas, antes, a genuína tarefa de uma aristocracia do espírito. Weber se empenhara - e se frustrara, muitas vezes -, todavia, em tentativas malsucedidas de arranjar um posto universitário condigno em Heidelberg ao seu "pranteado amigo Georg Simmel", cuja morte precoce lamenta em A política como vocação. O estorvo ao seu ingresso efetivo na carreira acadêmica não se devia, claro, ao simples fato de se deparar como um charmant invulgar em meio a suspeitosos catedráticos e ortodoxos burocratas cristãos; Simmel era plenamente consciente disso: sua condição judaica, os hábitos, as posturas e os maneirismos especificamente judeus [Ostjuden], sua fisionomia mesma bastava para Ihe inviabilizar a merecida consecução de uma cátedra na Prússia ou na Alemanha guilhermina, a despeito de seu prolífico rendimento intelectual ao longo de três décadas ininterruptas de magistério.

Simmel descendia em parte da tradição germânica do ensaio [Versuch], isto é, de tentativa, experimentação propriamente dita, aqui e ali animada por uma moral do trabalho para a qual, segundo Adorno, e como já disposto em "A coqueteria", a "felicidade" puramente subjetiva do "jogo" - em que se pode contemplar proposições as mais inusitadas - seria indispensável. Grosso modo, na percepção de Waizbort (2000, p. 35-72), o leitor histórico do ensaio almeja instrução, Bildung: anseio de um público de elite, diletante ou "burguês", como se costuma decretar em determinados círculos; e posto que a "cultura" é a clareira para a qual convergem todos os ensaios da Cultura filosófica, o leitmotiv de suas múltiplas reaparições ao longo da obra mesma, o ensaísmo de Simmel não teria como prosperar em meio ao ímpeto cientificista da sociologia, com a qual aparentemente nunca se deu bem, sobretudo se admitida, para agravar o quadro, a crônica obsolescência da noção oitocentista de formação.

No entanto, convém não perder de vista que, na fábula ${ }^{4}$ com a qual Simmel encerra a introdução de sua Cultura filosófica, os filhos do vinicultor só bem depois se dão conta de que o pai, em seu leito de morte, ao revelar a existência de um tesouro escondido em algum lugar da vinha, legava-lhes não uma relíquia propriamente dita, mas uma experiência rica, que apenas a escavação extenuante e contínua haveria de consumar - com a abundância inesperada das parreiras na próxima estação. No espírito do mesmo ensinamento, a tradução da Philosophische Kultur vem se somar ao legado de uma farta experiência intelectual cujo interesse Leopoldo Waizbort tem o condão de conformar e transmitir aos pesquisadores - ou agricultores? - que soube, ao longo dos anos, congregar de maneira hábil e contingente em seu torrão, empenhados no esforço acadêmico de sério cultivo de um Adorno, Auerbach, Benjamin, Curtius, Dilthey, Elias, Groethuysen, Jaffé, Kracauer, Luhmann,
4. Retomada e desenvolvida por W. Benjamin (1986 195-198) no ensaio "Experiência e pobreza". 
5. É digno de nota que uma fração dos melhores ensaios da Crítica filosófica já se encontrava na coletânea Simmel e a modernidade, organizada por Jessé de Souza (2014), quando ainda dedicado a cultivar obras (a serem) longamente maturadas, sem a atual preocupação imediata com as safras.
Simmel, Sombart, Stichweh, Warburg, Weber (um crescendo coincidente e admirável) e de tantos outros férteis grãos germânicos semeados no terreno ainda excessivamente gálico da sociologia brasileira. E o que é essa tradução, senão o fruto mesmo dessa cultura animosa, inclusiva, longânime, profícua? ${ }^{5}$ E qual seria o seu valor, se tal cultura não nos fosse vinculada pelo aprendizado, quando a própria sociologia de Simmel não é apenas um "experimento", como Lukács (2018: 331) atesta, mas também uma experiência, na acepção benjaminiana? O título da obra parece indicar essa sua natureza: cultura também entendida como cultivo e plantio, colheita e sazão; um quê ainda de orgânico e artesanal.

Pontuei no início que são conhecidas as comparações a que as vicissitudes da vida e da obra de Simmel parecem voluntariamente dar ensejo. Sem embargo das demais benesses que traz de chofre ao domínio sociológico em língua portuguesa, a edição da Cultura filosófica não constitui apenas um convite honesto para que Simmel adentre, afinal, livre e confortavelmente a sala de estar da sociologia, mas, acima de tudo, um reconhecimento oficial - ainda na verve da psicanálise - de que ele é, de fato, senhor em sua segunda casa. Que pode muito bem ser um chalé avarandado nas montanhas. Com jardins, lareira. E a quietude sugestiva de um pequeno ateliê.

\section{Referências}

BENJAMIN, Walter. Documentos de cultura, documentos de barbárie: escritos escolhidos (seleção e apresentação Willi Bolle). São Paulo: Cultrix; Editora USP, 1986 [1933].

HABERMAS, Jürgen. Textos e contextos. São Paulo: Editora Unesp, 2015 [1991].

HEIDEGGER, Martin; JASPERS, Karl. Briefwechsel: 1920-1963 (hg. von Walter Biemel und Hans Saner). Frankfurt am Main, DE: Vittorio Klostermann, 1990.

JUNG, Carl Gustav. Cartas: 1906-1945, v. I. Petrópolis, RJ: Vozes, 1999 [1943].

LUKÁCS, György. Georg Simmel. Dissonância: Revista de Teoria Crítica, v. 2, n. 2, p. 325-333, Segundo Semestre 2018 [1918].

MATA, Sérgio da. O escândalo da religião à luz da protossociologia de Thomas Luckmann. Sæculum, v. 30, p. 191-204, João Pessoa, Jan.-Jun. 2014.

PYYHTINEN, Olli. Simmel and "the social". London: Pallgrave Macm, 2010. 
SIMMEL, Georg. Essays on religion (editing and translante by Horst Jürgen Helle). New Haven, CT: Yale University Press, 2013.

SOUZA, Jessé de; ÖELZE, Berthold (Orgs.). Simmel e a modernidade, 2. ed. revista. Brasília: Editora UnB, 2014.

TÜRCKE, Christoph. O louco Nietzsche e a mania de razão. Petrópolis, RJ: Vozes, 1993.

WAIZBORT, Leopoldo. As aventuras de Simmel. São Paulo: Editora 34, 2000.

Simmel hoje: entrevista com Olli Pyyhtinen. Sociologia \& Antropologia, v. 5, n. 1, p. 11-30, Rio de Janeiro, Abr. 2015. 
